\title{
Relationship between the replicative age and cell volume in Saccharomyces cerevisiae
}

\author{
Renata Zadrag, Magdalena Kwolek-Mirek, Grzegorz Bartosz and Tomasz Bilinski ${ }^{\bowtie}$ \\ Department of Biochemistry and Cell Biology, University of Rzeszów, Rzeszów, Poland; \\ 凶e-mail: bilinski@univ.rzeszow.pl
}

Received: 10 June, 2006; revised: 25 September, 2006; accepted: 09 October, 2006 available on-line: 14 November, 2006

\begin{abstract}
Reaching the limit of cell divisions, a phenomenon referred to as replicative aging, of the yeast Saccharomyces cerevisiae involves a progressive increase in the cell volume. However, the exact relationship between the number of cell divisions accomplished (replicative age), the potential for further divisions and yeast cell volume has not been investigated thoroughly. In this study an increase of the yeast cell volume was achieved by treatment with pheromone $\alpha$ for up to 18 h. Plotting the number of cell divisions (replicative life span) of the pheromone-treated cells as a function of the cell volume attained during the treatment showed an inverse linear relationship. An analogous inverse relationship between the initial cell volume and replicative life span was found for the progeny of the pheromone-treated yeast. This phenomenon indicates that attaining an excessive volume may be a factor contributing to the limitation of cellular divisions of yeast cells.
\end{abstract}

Keywords: yeast, Saccharomyces cerevisiae, replicative aging, cell volume

\section{INTRODUCTION}

The budding yeast Saccharomyces cerevisiae is a very useful experimental object due to its simplicity, easy culturing and genetic manipulation, and a short cellular life span of tens of hours. A single yeast cell can undergo a limited number of divisions (referred to as the replicative life span) which suggests an analogy with the Hayflick limit. This eukaryotic microorganism has become a unicellular model organism in studies of aging (Jazwinski et al., 1989; Sinclair et al., 1998; Gershon \& Gershon, 2000; Sinclair, 2002; Bitterman et al., 2003). Among the features which accompany approaching the division limit (i.e. replicative aging) in S. cerevisiae, the increase in cell volume is apparently the most obvious (Jazwinski et al., 1989). However, the exact relationship between the replicative age, the potential for further divisions and the cell volume has evaded systematical analysis (Egilmez \& Jazwinski, 1989). Pioneers of yeast aging research considered the cell volume as a factor which can limit the replicative life span by decreasing the surface-to-volume ratio (Mortimer \& Johnston, 1959) but this idea has not been followed up. Later on, Kennedy et al. (1994) addressed the question whether the increase in cell volume evoked by pheromone $\alpha$ treatment affects yeast replicative life span, finding no meaningful effect of a 4-h treatment (Kennedy et al., 1994). We have come to an opposite conclusion when reinvestigating this question and using longer incubation times with the pheromone (Zadrag et al., 2005).

This study was aimed at an analysis of the dependence between the replicative age of the yeast and its cell volume.

\section{MATERIAL AND METHODS}

Yeast strains and culture. Two isogenic strains: DSCD1-1C $\Delta$ sod1 mutant (Bilinski et al., 1985) and D1CSP4-8C (MATa leu1 arg4), a wild-type strain, a cross of SP-4 (Bilinski et al., 1978) and DSCD1-1C, was used. Yeast was grown in a standard liquid YP-

Abbreviations: $\mathrm{Cu}, \mathrm{Zn}-\mathrm{SOD}, \mathrm{Cu}, \mathrm{Zn}$-superoxide dismutase; PK60S, protein kinase $60 \mathrm{~S}$ ribosomal subunit; rDNA, ribosomal DNA; YPD, yeast extract-peptone-dextrose. 
Dextrose medium (1\% Difco Yeast Extract, 1\% Yeast Bacto-Peptone, $2 \%$ glucose) on a rotary shaker at 150 r.p.m. or on a solid YPD medium containing 2\% agar, at a temperature of $30^{\circ} \mathrm{C}$.

Pheromone treatment. Virgin cells (buds) were isolated by centrifugation in a sucrose (10-30\%) density gradient. The bud suspension in YPD medium $\left(10^{6}\right.$ cells $\left./ \mathrm{ml}\right)$ was spun down, re-suspended in fresh medium and treated with pheromone $\alpha$ (BioVectra, DCL, Canada) at a final concentration of 5 $\mu \mathrm{M}$. The cell suspensions were incubated on a shaker (150 r.p.m., $\left.30^{\circ} \mathrm{C}\right)$ for various time intervals. In order to counteract the effect of pheromone degradation, a fresh portion of the pheromone (up to extra $5 \mu \mathrm{M}$ ) was added after 8-9 h. After appropriate time intervals the cells were centrifuged and transferred onto fresh solid YPD medium.

Determination of replicative life span. The life span of individual yeast cells was determined by a routine procedure (Kim et al., 1999; Wawryn et al., 1999) on cells placed on agar plates using a micromanipulator. The number of buds formed by each cell is referred to as its replicative life span. Results of two independent experiments, each on at least 40 cells, were taken for each experimental point.

Estimation of cell volume. Cell volume was evaluated by analysis of microscopic images of the cells assuming that it is the sum of volumes of circular slices into which the cell can be divided (Wojnar et al., 2002). Such an attitude was adopted due to the shape irregularity of the shmoo (elongated cell formed in response to the pheromone).

Estimation of protein content of yeast cells. Protein content of yeast cells was estimated fluorimetrically with Nano Orange (Molecular Probes) in a Hitachi F-2500 spectrofluorimeter. Briefly, yeast suspension was centrifuged and the sediment was suspended in sterile distilled water to obtain a density of $10^{8}-10^{9}$ cells $/ \mathrm{ml}$, mixed with an equal volume of ice-cold $10 \%$ trichloroacetic acid, vortexed intensively for $1 \mathrm{~min}$ and placed on ice for $5 \mathrm{~min}$ and centrifuged. The precipitate was washed several times with water and suspended in distilled water.

Aliquots of $10 \mu \mathrm{l}$ of the suspension were added to $2.5 \mathrm{ml}$ of Nano Orange solution, incubated at $95^{\circ} \mathrm{C}$ for $10 \mathrm{~min}$ and cooled at room temperature for $20 \mathrm{~min}$. Fluorescence was then measured at excitation and emission wavelengths of $470 \mathrm{~nm}$ and 570 $\mathrm{nm}$, respectively. Protein content was read from a standard curve obtained for bovine serum albumin.

\section{RESULTS AND DISCUSSION}

We found a roughly constant rate of increase of the cell volume of dividing mother cells of S. cerevisiae, up to 40 buddings for the D1CSP4-8C strain and 15 buddings for the DSCD1-1C strain (Fig. 1a). During this time, the volume of the mother cells of D1CSP4-8C strain increased more than 10-fold (Zadrag et al., 2005). When the cells were prevented from dividing by pheromone $\alpha$ treatment (in the shmoo state), their volume increased approximately exponentially for up to $12 \mathrm{~h}$ (D1CSP4-8C) and $10 \mathrm{~h}$ (DSCD1-1C), respectively (Fig. 1b). In both cases the rate of volume growth was higher for the short-lived DSCD1-1C strain, devoid of $\mathrm{Cu}, \mathrm{Zn}$-superoxide dismutase $(\mathrm{Cu}, \mathrm{Zn}-\mathrm{SOD})$ than for its wild-type counterpart. When plotted versus time, the final volume of the shmoo cells exceeded the initial one 12-fold and 17-fold for the D1CSP4-8C and DSCD1-1C strains, respectively.

We compared the rate of cell growth in the shmoo state of the two strains studied with their growth without inhibition of cell divisions. Since there was a good correlation between the cell volume and protein content (not shown), we estimated the protein content of cells arrested in the shmoo state and calculated how much protein they would produce if they continued budding during this time. The results of such comparisons (Table 1) demonstrate that the growth rate of the wild-type D1CSP4-
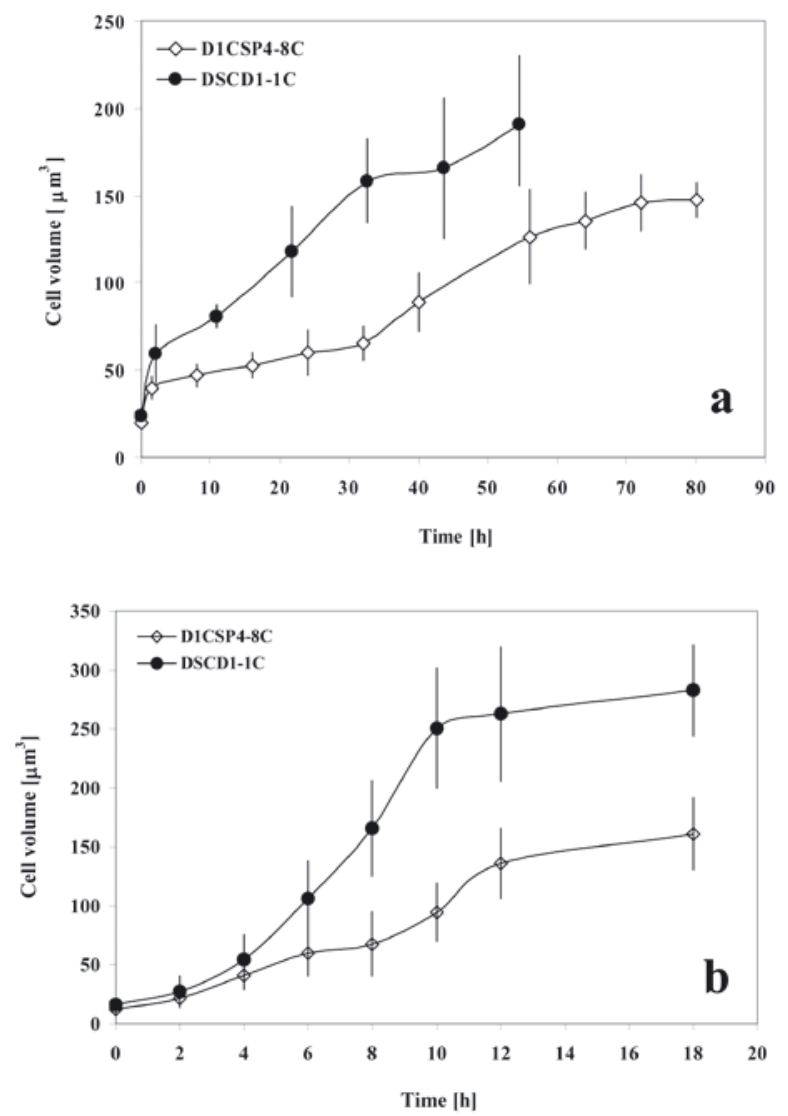

Figure 1. Cell volume increase as a function of time during normal replicative growth (a) and of time without cell divisions during replication arrest in the shmoo state (b) for cells of D1CSP4-8C (wild type strain) and DSCD1-1C ( $\Delta$ sod1 mutant). 
Table 1. Net protein production by yeast cells under division arrest and calculated protein production by the cells had they continued budding, for cells of the D1CSP4-8C and DSCD1-1C strains.

\begin{tabular}{|c|c|c|c|c|c|c|c|c|}
\hline \multirow[t]{2}{*}{$\begin{array}{l}\text { Duration } \\
\text { of division } \\
\text { arrest }[\mathrm{h}]\end{array}$} & \multicolumn{2}{|c|}{$\begin{array}{l}\text { Net protein production } \\
\text { per cell }[\mathrm{pg}] \text { (a) }\end{array}$} & \multicolumn{2}{|c|}{$\begin{array}{l}\text { Number of buds which } \\
\text { could be produced dur- } \\
\text { ing this time }\end{array}$} & \multicolumn{2}{|c|}{$\begin{array}{l}\text { Amount of protein } \\
\text { needed to produce such } \\
\text { amount of buds (b) }\end{array}$} & \multicolumn{2}{|c|}{$a / b$} \\
\hline & D1CSP4-8C & DSCD1-1C & D1CSP4-8C & DSCD1-1C & D1CSP4-8C & DSCD1-1C & D1CSP4-8C & DSCD1-1C \\
\hline 4 & 3.00 & 4.35 & 2.5 & 1.8 & 3.00 & 2.25 & 1.00 & 1.93 \\
\hline 9 & 8.49 & 9.40 & 5.6 & 4.1 & 6.70 & 5.12 & 1.20 & 1.80 \\
\hline 12 & 9.67 & 12.90 & 7.5 & 5.5 & 9.00 & 6.90 & 1.10 & 1.80 \\
\hline 18 & 13.25 & 15.60 & 11.25 & 8.2 & 13.50 & 10.25 & 0.98 & 1.50 \\
\hline & & & & & & Mean & 1.07 & 1.80 \\
\hline
\end{tabular}

The calculations were done assuming the protein content of $1.20 \mathrm{pg}$ and $1.25 \mathrm{pg}$ per bud of D1CSP4-8C and DSCD1-1C strains, respectively, initial protein content of cells arrested for $4 \mathrm{~h}$ of 3.00 and $4.35 \mathrm{pg}$, respectively, and mean generation time of 96 and $131 \mathrm{~min}$ for cells of the D1CSP4-8C and DSCD1-1C strains, respectively.

8C strain under conditions of division arrest remains controlled and is comparable to that of dividing cells, while cells of the DSCD1-1C strain seem to loose the control of the rate of protein synthesis in the shmoo state. This may be due to the fact that the $\mathrm{Cu}, \mathrm{Zn}$-SOD protein (SOD1) is an inhibitor of PK60S kinase controlling the translational activity of the ribosomes (Zielinski et al., 2002; Abramczyk et al.,
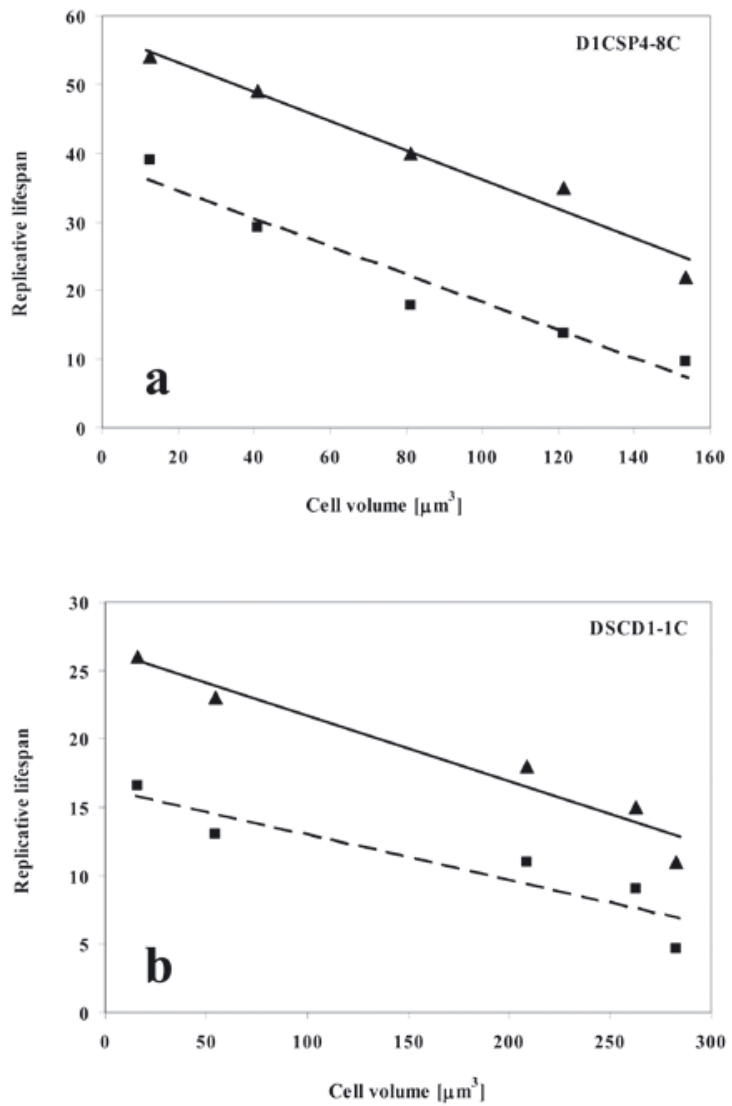

Figure 2. Dependence of mean and maximal number of residual divisions on the volume of pheromone-treated yeast cells.

a. D1CSP4-8C strain; b. DSCD1-1C strain. Squares, mean number of residual divisions; triangles, maximal number of residual divisions. The calculations are based on data of Zadrag et al. (2005).
2003), a function independent of the antioxidant action of this enzyme. The deficiency of this protein in the $\Delta \operatorname{sod} 1$ mutant leads to the functioning of the translational system of the cell at a higher rate, and in consequence to an excessive increase in protein synthesis and cell size.

Comparison of the data for the two strains studied showed that the DSCD1-1C strain which grew in volume at a two times faster rate than the D1CSP4-8C strain had a two times shorter replicative life span. This prompted us to examine the relationship between the cell volume and the replicative life span of the yeast cells. Plotting the replicative life span of pheromone-treated cells (after removing the pheromone and allowing for resuming cell divisions) (Zadrag et al., 2005) as a function of cell volume attained during the treatment showed an inverse linear relationship (Fig. 2). This result suggests that attaining a sufficiently high volume may be a factor contributing to the limitation of cellular divisions.

However, a pheromone $\alpha$-treated yeast cell has an irregular, toroid shape, of a higher surface to volume ratio than a typical cell, which may affect the course of processes dependent on the transport of molecules. In order to be able to compare the replicative life span of cells of different size but of the same shape, another attitude had to be used.

We took advantage of the fact that buds of large shmoo cells, especially of the $\Delta$ sod 1 mutant, have a much larger size than normal cells but are of a typical regular shape. These cells have an additional advantage that they do not experience the possible mating-specific metabolic effects of the pheromone. Measurements of the volume and the replicative life span of the first buds of shmoo cells formed after removal of pheromone demonstrate that the decrease in the volume of successive generations of the first buds is accompanied by their increasing replicative life span (Fig. 3a and b). These data demonstrate that only the size and not the shape of the cell has a dominant effect on the number of buds, and that the 


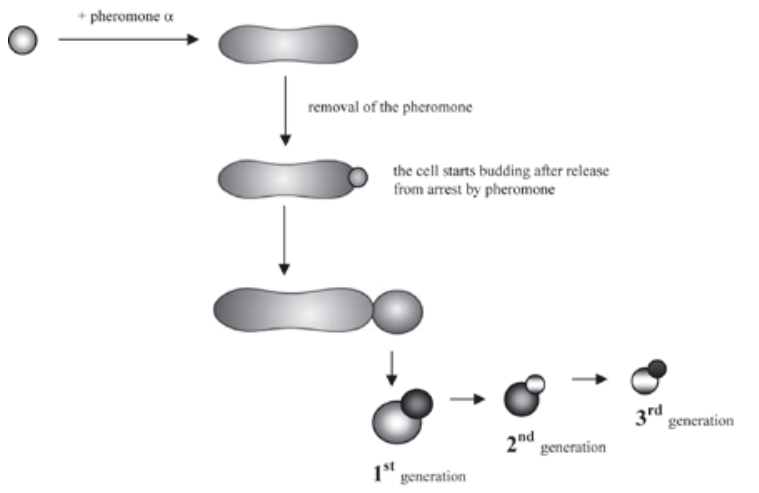

h

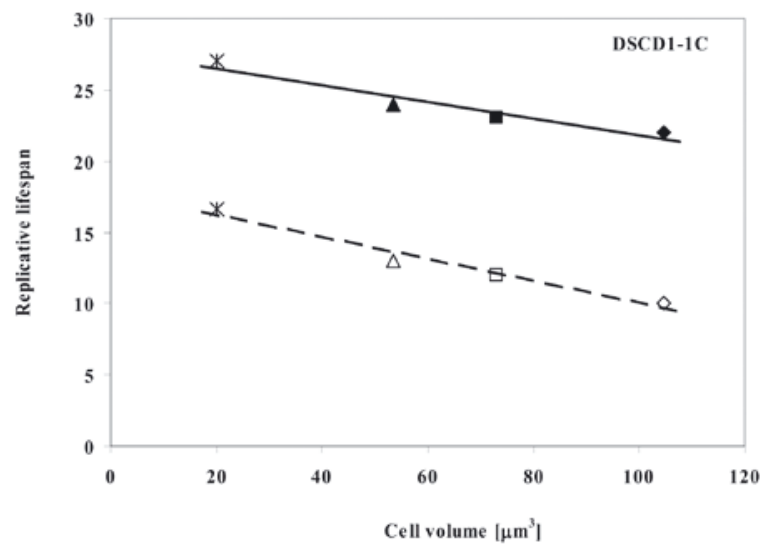

Figure 3. Dependence of replicative life span on the volume of progeny of pheromone-treated cells.

a. Scheme of the experimental procedure; b. Dependence of mean (empty symbols) and maximal life span (full symbols) on the initial volume of progeny of pheromonetreated cells. Successive generations (1st, i.e. daughters, diamonds, 2nd, i.e. granddaughters, squares, and 3rd, i.e. grand granddaughters, triangles) of shmoo cells treated for $18 \mathrm{~h}$ with the pheromone were used in order to obtain virgin cells of various initial volume. Stars, data for a normal typical bud (derived from a cell not treated with the pheromone) of the DSCD1-1C strain.

linear dependence of the replicative life span on the volume is not due to the action of the pheromone.

The limited replicative life span of $S$. cerevisiae has been attributed to the accumulation of a "senescence factor" in the aging mother cell (Egilmez \& Jazwinski, 1989). The nature of the senescence factor remains elusive but most authors identify it with extrachromosomal rDNA circles (Guarente, 2000; Bitterman et al., 2003). It has been demonstrated by mathematical modeling, however, that merely formation of rDNA circles is not sufficient to account for the shape of the survival curves of yeast cells (Gillespie et al., 2004). Perhaps the effect of attaining a critically high cell volume could be another factor contributing to this phenomenon.

A similar inverse relationship between the cell size and number of cell divisions has been noted previously for human fibroblasts in culture (Angello et al., 1987; 1989) and, more recently, for normal and neoplastic cells under conditions of prolonged unbalanced growth induced by suppression of cell divisions (Sumikawa et al., 2005). Its mechanism may involve an increasing inability to control critical processes of a giant cell by the nucleus which does not increase in size, e.g. to attain the threshold concentration of factor(s) required for the initiation of DNA synthesis (Angello et al., 1989). It seems that this idea of the effect of increasing cell volume on the limitation of replicative capacity should be considered also for the yeast $S$. cerevisiae which, due to the asymmetrical way of cell division, is bound to experience a cell/nucleus size imbalance with successive buddings. The higher rate of the loss of the replicative potential of cells in the shmoo state as compared with the replicating cells found by us (Zadrag et al., 2005) is in line with this interpretation. Although the Hayflick limit of mammalian cells is attributed to the lack of telomerase activity and, in consequence, telomere shortening, the effect of the excessive increase in volume on the cellular capacity for division cannot be neglected. Apparently, two parallel mechanisms limiting the division potential of cells can exist both in mammalian cells and in the yeast, one of them being attaining a critical cell volume.

\section{Acknowledgements}

This work was supported by Grant No. 6 P04A07920 from the State Committee for Scientific Research (KBN, Poland).

\section{REFERENCES}

Abramczyk O, Zien P, Zielinski R, Pilecki M, Hellman U, Szyszka R (2003) The protein kinase $60 \mathrm{~S}$ is a free catalytic CK $2 \alpha^{\prime}$ subunit and forms an inactive complex with superoxide dismutase SOD1. Biochem Biophys Res Commun 307: 31-40.

Angello JC, Pendergrass WR, Norwood TH, Prothero J (1987) Proliferative potential of human fibroblasts: an inverse dependence on cell size. J Cell Physiol 132: 125130.

Angello JC, Pendergrass WR, Norwood TH, Prothero J (1989) Cell enlargement: one possible mechanism underlying cellular senescence. J Cell Physiol 140: 288-294.

Bilinski T, Lukaszkiewicz J, Sledziewski A (1978) Demonstration of anaerobic catalase synthesis in the $c z 1$ mutant of Saccharomyces cerevisiae. Biochem Biophys Res Commun 83: 1225-1233.

Bilinski T, Krawiec Z, Liczmanski A, Litwinska J (1985) Is hydroxyl radical generated by the Fenton reaction in vivo? Biochem Biophys Res Commun 130: 533-539.

Bitterman KJ, Medvedik O, Sinclair DA (2003) Longevity regulation in Saccharomyces cerevisiae: linking metabolism, genome stability, and heterochromatin. Microbiol Mol Biol Rev 67: 376-399.

Egilmez NK, Jazwinski SM (1989) Evidence for the involvement of a cytoplasmic factor in the aging of the yeast Saccharomyces cerevisiae. J Bacteriol 171: 37-42. 
Gershon H, Gershon D (2000) The budding yeast, Saccharomyces cerevisiae, as a model for aging research: a critical review. Mech Ageing Dev 120: 1-22.

Gillespie CS, Proctor CJ, Boys RJ, Shanley DP, Wilkinson DJ, Kirkwood TB (2004) A mathematical model of ageing in yeast. J Theor Biol 229: 189-196.

Guarente L (2000) Sir2 links chromatin silencing, metabolism, and aging. Genes Dev 14: 1021-1026.

Jazwinski SM, Egilmez NK, Chen JB (1989) Replication control and cellular life span. Exp Gerontol 24: 423-436.

Kennedy BK, Austriaco NR Jr, Guarente L (1994) Daughter cells of Saccharomyces cerevisiae from old mothers display a reduced life span. J Cell Biol 127: 1985-1993.

Kim S, Kirchman PA, Benguria A, Jazwinski SM (1999) Experimentation with the yeast model. In Methods in Aging Research (Yu BP, ed) vol 1, pp 191-213. CRC Press, Boca Raton, Boston, London, New York, Washington, DC.

Mortimer RK, Johnston JR (1959) Life span of individual yeast cells. Nature 183: 1751-1752.

Sinclair DA (2002) Paradigms and pitfalls of yeast longevity research. Mech Ageing Dev 123: 857-867.
Sinclair DA, Mills K, Guarente L (1998) Molecular mechanisms of yeast aging. Trends Biochem Sci 23: 131-134.

Sumikawa E, Matsumoto Y, Sakemura R, Fujii M, Ayusawa D (2005) Prolonged unbalanced growth induces cellular senescence markers linked with mechano transduction in normal and tumor cells. Biochem Biophys Res Commun 335: 558-565.

Wawryn J, Krzepilko A, Myszka A, Bilinski T (1999) Deficiency in superoxide dismutases shortens life span of yeast cells. Acta Biochim Polon 46: 249-253.

Wojnar L, Kurzydlowski KJ, Szala J (2002) Praktyka analizy obrazu. Polskie Towarzystwo Stereologiczne, Kraków.

Zadrag R, Bartosz G, Bilinski T (2005) Replicative aging of the yeast does not require DNA replication. Biochem Biophys Res Commun 333: 138-141.

Zielinski R, Pilecki M, Kubinski K, Zien P, Hellman U, Szyszka R (2002) Inhibition of yeast ribosomal stalk phosphorylation by $\mathrm{Cu}-\mathrm{Zn}$ superoxide dismutase. Biochem Biophys Res Commun 296: 1310-1316. 